\title{
This is Your Brain on Neuroscience
}

Link to publication record in Manchester Research Explorer

\section{Citation for published version (APA):}

Balmer, A. S. (2014). This is Your Brain on Neuroscience.

\section{Citing this paper}

Please note that where the full-text provided on Manchester Research Explorer is the Author Accepted Manuscript or Proof version this may differ from the final Published version. If citing, it is advised that you check and use the publisher's definitive version.

\section{General rights}

Copyright and moral rights for the publications made accessible in the Research Explorer are retained by the authors and/or other copyright owners and it is a condition of accessing publications that users recognise and abide by the legal requirements associated with these rights.

\section{Takedown policy}

If you believe that this document breaches copyright please refer to the University of Manchester's Takedown Procedures [http://man.ac.uk/04Y6Bo] or contact uml.scholarlycommunications@manchester.ac.uk providing relevant details, so we can investigate your claim.

\section{OPEN ACCESS}




\section{This is Your Brain on Neuroscience}

\section{Andrew S. Balmer, Department of Sociology, University of Manchester, UK.}

Pickersgill, M. and van Keulen, I. (Eds) Sociological Reflections on the Neurosciences, Bingley UK: Emerald Group Publishing, 2011, f77.95 (hardback) 324 pp, ISBN: 978-1-84855-880-9.

On an infrequent trip to the gym recently I noticed in the timetable, nestled amongst the many fads for group workouts, a class called 'Train for your Brain'. Given my lack of interest in group training of any sort it would ordinarily have passed me by, but it piqued my interest in the dispersal of findings, terminologies and practices of social neuroscience. I'm perhaps more tuned-in to the increasing marketing of products by reference to the brain, but I think any casual observer would recognise it too. Indeed, only a few moments later in the gym, passing the vending machine a little further down the corridor, I could have purchased any one of a number of neuro-themed drinks, that variously promised to help me bring about 'neurobliss', 'neurosleep' or a 'neurogasm'.

This neuro-creep is now quite well-theorised as regards contemporary work on the 'neurochemical self' or 'cerebral subject', which has argued that the self is increasingly conflated with the brain. However, there is still a lack of empirical heft to the claims made about this apparent transformation of selfhood. Fortunately, if there's one thing that the authors in Pickersgill and Van Keulen's collection can be said to have in common, it is an orientation to the empirical exploration of the premise that we are increasingly called-upon to make sense of ourselves by reference to our brains.

Of course, being part of a medical sociology series the book is less concerned with gym timetables and vending machines and instead focusses largely on a number of pathologies and social 'abnormalities' that help to shed light on the ways in which neuroscience research is developed, made use of in clinical contexts, and understood by those living with various mental health problems. So, for example, one finds Rayna Rapp's chapter on ADHD ('A Child Surrounds this Brain') invoking the various social relationships that are embedded in the practices of neuroscience researchers when recruiting research participants, shepherding them through the brain scanning process, and then standardising, manipulating and interpreting the collected data. In Julie Netherland's contribution ("We Haven't Sliced Open Anyone's Brain Yet"') we find the brain and its chemistry enrolled into and contrasted with various other narratives of addiction as her participants make sense of the experience of taking methadone or buprenorphine. Indeed, the argument that neuroscience information is articulated in concert with a wealth of other accounts of behaviour can be found throughout the book, and its return as a finding in different contexts suggests that some of the empirical work has been organised as a counter to, or at least as a way of nuancing, the bolder claim that the neuro is somehow redefining subjectivity at large. That our explanations of ourselves, our relationships and social order more generally are multiple and sit more or less comfortably alongside each other is unlikely to surprise readers of Symbolic Interactionism. However, the presence of neuro accounts in these various contexts does, collectively, suggest that brains - in their various ontologies as neurons, networks, scans, chemicals, and so on - are now to be made sense of and to be made use of in our making sense.

Overall, the book presents an interesting and generally engaging collection, which covers a diverse range of contexts, repeatedly invoking those perennial questions about how we account for ourselves, illness and abnormality. However, I think there are some real standout pieces worth noting individually. For example, Baptiste Moutaud's ('Are We Receptive to Naturalistic Models of our Disease Experience?') comparison of the experience of deep brain stimulation (DBS) for those suffering from Parkinson's and obsessive compulsive disorder is enlightening as regards how those 
people made sense of the failure of DBS to completely normalise their lives. In particular, however, I was left with an impression of Elizabeth Fein's ('Innocent Machines') sensitive and critical investigation of the developing neuroscience of Asperger's Syndrome (AS). Looking into this world of 'innocent machines', Fein charts a split between two understandings of our brain, broadly under the banners of the 'neurochemical self', an adjustable and plastic brain, offering the opportunity to remake oneself according to one's life projects, and the 'neurostructural self', a concrete brain, predisposed to particular dispositions which just have to be accepted. Fein's account was also the most compelling demonstration, to my mind, of the way in which the brain, neurochemicals and psychopharmaceuticals are used in narratives of responsibility and ethics, and in the marshalling of resources to change social organisation. Mothers of children with Asperger's Syndrome found solace in the neurostructural self, and released themselves of the guilt that decades of explanations of AS had forced them to bare, and made use of neuroscience accounts in their campaigns to provide free specialist (and quite elite, it would seem) education for their children.

It is these kinds of observations that make the book a good read, and it is at its strongest when dealing with the rise of the brain in the world of human meanings and social organisation. My feeling is that the collection perhaps pulls some of its punches, though, particularly when it comes to the potential of reading neuroscience into social theory and vice versa. Although Christian von Scheve's (Sociology of Neuroscience or Neurosociology?) analysis raises the possibility of such a reading, it makes little headway in that project. But maybe that's just a little too much to ask from one volume and so I think instead it would be fairer to say that the book marks a good step in that direction by providing material for those interested in renewing the long project of bringing the social and somatic more firmly into critical relation. 